Article

\title{
Energy and Material Flows and Carbon Footprint Assessment Concerning the Production of HMF and Furfural from a Cellulosic Biomass
}

\author{
Hannes Schöppe ${ }^{1}$, Peter Kleine-Möllhoff ${ }^{1, *(D)}$ and Rolf Epple ${ }^{2}$ \\ 1 ESB Business School, Reutlingen University, 72762 Reutlingen, Germany; Hannes.schoeppe@web.de \\ 2 Reutlingen Research Institute, Reutlingen University, 72762 Reutlingen, Germany; \\ rolf.epple@reutlingen-university.de \\ * Correspondence: Peter.Kleine-Moellhoff@Reutlingen-University.de; Tel.: +49-7121-271-5009
}

Received: 20 December 2019; Accepted: 13 January 2020; Published: 17 January 2020

\begin{abstract}
HMF) and furfural are interesting as potential platform chemicals for a bio-based chemical production economy. Within the scope of this work, the process routes under technical development for the production of these platform chemicals were investigated. For two selected processes, the material and energy flows, as well as the carbon footprint, were examined in detail. The possible production process optimizations, further development potentials, and the research demand against the background of the reduction of the primary energy expenditure were worked out.
\end{abstract}

Keywords: bio-based chemical production; material and energy flows; carbon footprint; furfural; 5-hydroxymethylfurfural; HMF

\section{Introduction}

The chemical industry builds its value chains on relatively few raw materials. The basic feedstock of the chemical industry is made up of an organic part and an inorganic part. On this basis, German chemical companies, for example, produce around 30,000 different intermediate and end products in numerous chemical plants [1]. Globally, the chemical industry is a key driver of the demand for crude oil [2]. Carbon (C) is the basis of the value chain in organic chemistry, and is extracted from natural gas, coal, and, in part, from renewable and thus bio-based raw materials, in addition to crude oil [1]. Renewable raw materials have a long tradition in the chemical industry, and vegetable oil, animal fat, starch, or sugar still represent the carbon base in special applications. In Germany, renewable raw materials account for about $13 \%$ of all carbon-containing raw materials [3].

A widely used definition of biorefineries was formulated by the International Energy Agency Bioenergy Task 42, namely: "Biorefinery is the sustainable processing of biomass into a spectrum of marketable products (food, feed, materials, and chemicals) and energy (fuels, power, and heat)" [4]. Therefore, economic and environmental aspects are key to the development of a bio-based chemistry that makes use of biorefineries. In this regard, the development of economically feasible and environmentally benign routes should be prioritized [5].

The United States Department of Energy identified 5-Hydroxymethyl-Furfural (HMF) and furfural as two of the top ten value-added bio-based chemicals [6]. HMF and furfural are produced by chemical catalytic processes, while the remaining bio-based platform chemicals are mainly produced by fermentation [7]. Different production process routes are proposed for these two platform chemicals of the bio-based chemistry, but few are applied on an industrial or near-industrial scale [8,9]. Publicly available information about the environmental performance of the chemical production processes is scarce. 
In the context of this work, different production process routes for the two chemicals, HMF and furfural, will be analyzed with regard to their structure, the state of the art, and new developments. For two selected process routes, the largest environmental impacts will be analyzed and verified via a detailed process analysis.

The results of the present work will be used to critically examine the development of a new biorefinery in relation to existing processes.

\section{Materials and Methods}

With the help of a literature review, the current manufacturing processes, the users, and the producers of the bio-based platform chemicals HMF and furfural were identified.

For each molecule, one process was selected for further analysis. Data availability was the basic condition, as it is a necessary foundation for all further analyses. In addition, feasibility on an industrial scale, and, in case of established processes, the market position were included in the selection. The selected production processes of these two processes have subsequently been analyzed in detail. The information on the material and energy flows given in the process description was checked. For this purpose, an input-output table was created for each process step. Based on these data, the resulting environmental impacts were then added for each process step. For the modelling of the environmental impacts, a procedural review was carried out, and information from the relevant databases were included and compared with the process balances at the level of the individual processes. The analysis of the environmental impacts was limited to the energy demand and $\mathrm{CO}_{2}$ emissions of the respective processes. In Chapter 3.1 an example of the procedure is shown. More details can be found in the Supplementary Material. Assumptions such as pressure losses, efficiency of pumps and fans, and operating times have been marked. The influence of the estimates on energy consumption and $\mathrm{CO}_{2}$ emissions was checked by means of sensitivity analyses.

\section{Use, Producers, and Process Routes for the Production of 5-Hydroxymethylfurfural and Furfural}

\subsection{5-Hydroxmethylfurfural}

HMF is an organic compound that forms during the thermal decomposition of carbohydrates. For example, HMF can be detected in many foods that have undergone heat treatment, such as milk, fruit juice, honey, or coffee. When sugar is heated in a frying pan, the compound is noticeable as a caramel-like odor [10]. HMF is one of the most important platform chemicals in bio-based chemistry [6].

HMF can be obtained from plant biomass. The synthesis of HMF by the acid-induced elimination of three moles of water from saccharides has been known for many years. The most common catalysts used are mineral acids (such as $\mathrm{H}_{2} \mathrm{SO}_{4}, \mathrm{H}_{3} \mathrm{PO}_{4}$, and $\mathrm{HCl}$ ), organic acids (such as oxalic, levulinic, and p-toluene sulfonic acids (PTSAs)), solid acids, transition metal ions, and ion exchange resins [11]. Sugar cane, sugar beet, sorghum, chicory, Jerusalem artichoke, wheat, corn, and potatoes can be used as raw materials. Some of these have to be enzymatically isomerized into fructose, which can be converted into HMF by water separation [12].

HMF serves as an intermediate for the production of the biofuel dimethylfuran (DMF), and can also be used for key molecules such as levulinic acid, 2,5-furanedicarboxylic acid (FDA), 2,5-diformylfuran (DFF), dihydroxymethylfuran, and 5-hydroxy-4-keto-2-pentenoic acid [13]. HMF can serve as a starting material for various innovative materials, especially polymers, with specific properties [7].

The production of HMF on an industrial scale is a challenge [10]. Therefore, intensive research is currently underway to develop efficient, cost-effective, and sustainable commercial methods for the production of HMF [14]. Table 1 shows three process alternatives for the synthesis of HMF from fructose. 
Table 1. Three process alternatives for the synthesis of 5-hydroxymethyl-furfural (HMF) from fructose (according to the literature [12]).

\begin{tabular}{ccc}
\hline Process & Advantages & Disadvantages \\
\hline $\begin{array}{c}\text { Reaction in water with sulfuric } \\
\text { acid as catalyst }\end{array}$ & $\begin{array}{c}\text { HMF is relatively easy to } \\
\text { obtain in pure form }\end{array}$ & Non-optimal yields of 50-60\% \\
\hline $\begin{array}{c}\text { Elimination of water in dimethyl } \\
\text { sulfoxide (DMSO) as a solvent }\end{array}$ & High turnover & $\begin{array}{c}\text { Difficult separation of product } \\
\text { from solvent }\end{array}$ \\
\hline $\begin{array}{c}\text { Elimination of water in } \\
\text { multiphase reaction mixtures }\end{array}$ & $\begin{array}{c}\text { HMF can be obtained } \\
\text { continuously }\end{array}$ & $\begin{array}{c}\text { HMF is highly } \\
\text { soluble in water }\end{array}$ \\
\hline
\end{tabular}

In 2018, researchers around Michael-Alexander Kougioumtzis of the National Technical University of Athens developed a process for the production of HMF from a cellulosic biomass. Hydrolysis is carried out in an aqueous medium, while glucose is dehydrated in a dimethyl sulfoxide DMSO $/ \mathrm{H}_{2} \mathrm{O}$ mixture [15].

In contrast to other methods of HMF production, the mass and energy balances of this process are readily accessible to the public. For this reason, the process presented in the literature [15] was subjected to an in-depth process analysis within the scope of this work.

Table 2 shows an example of the procedure for checking the energy and material flows for the hydrolysis preheating step in HMF production, according to the authors of [15]. In the literature, a power requirement of $3341 \mathrm{~kW}$ was stated for this process step. The examination by the authors results in a power requirement of $3397 \mathrm{~kW}$ with the given material flow and the process parameters. With the assumed value for energy efficiency being $70 \%$ for this process step, this result differs by $2 \%$ from the value given in the literature, and was therefore assessed as correct with regard to the verification. With the calculated power value and an assumed operating time of $6500 \mathrm{~h}$ per year, the specific power requirement per kilogram of produced HMF was calculated.

Table 2. Example for verifying the power requirement and calculating the specific energy requirement of a given process step.

\begin{tabular}{cccc}
\hline \multicolumn{4}{c}{ HMF Hydrolysis Preheating } \\
\hline Parameter & Number & Unit & Source \\
\hline Given heat demand & 3341 & $\mathrm{~kW}$ & {$[15]$} \\
Throughput & 4.20 & $\mathrm{~kg} / \mathrm{s}$ & {$[15]$} \\
Temperature 1 (end) & 170 & ${ }^{\circ} \mathrm{C}$ & {$[15]$} \\
Temperature 2 (start) & 25 & ${ }^{\circ} \mathrm{C}$ & {$[15]$} \\
Spec. heat capacity & 3.91 & $\mathrm{~kJ} /(\mathrm{kg} \mathrm{K})$ & calculation for mixture of substances \\
Efficiency & 70 & $\%$ & assumption \\
Calculated heat demand & 3397 & $\mathrm{~kW}$ & calculation \\
Operating time & 6500 & $\mathrm{~h} / \mathrm{a}$ & assumption \\
Specific heat demand & 62.91 & $\mathrm{kWh} / \mathrm{kg} \mathrm{HMF}$ & calculation \\
\hline
\end{tabular}

\subsection{Furfural}

Furfural is a natural dehydration product of the C 5 sugar xylose, a monosaccharide that often is found in large amounts in the hemicellulose fraction of the lignocellulosic biomass from which it is almost exclusively produced [9].

Furfural is obtained from the pentosan-containing fraction of lignocellulose. The C5 sugars contained herein (especially xylose) are first separated into monosaccharides by acid hydrolysis. These monosaccharides are then dehydrated and furfural is formed. Both batch and continuous reactors are used industrially [16].

More than 80 chemicals are directly or indirectly derived from furfural [17]. It was therefore identified as one of the key chemicals in lignocellulosic biorefineries [6]. 
The most important raw materials for furfural production are corncobs, rice husks, flax residues, cottonseed shells, wood, and bagasse obtained from sugar cane [18]. These plant-based materials with a higher pentosan content allow for a higher yield of furfural. Today, bagasse and corncobs account for more than $98 \%$ of all raw materials used in the production of furfural, as they are inexpensive and readily available from sugar cane and corn processing plants, in addition to their high pentosan content [9].

The current most important use of furfural is as a starting material for the production of furfuryl alcohol and other five-membered oxygen-containing heterocycles, such as furan, methylfuran, furfurylamine, and furoic acid. [17]. Furfuryl alcohol is a monomer for furan resins, which are mainly used as foundry binding agents. It is produced by the hydrogenation of furfural [19]. About $60 \%$ to $70 \%$ of the total furfural production of about 300,000 tons per year (2001) is processed into furfuryl alcohol [16]. Furfural is also a starting material for tetrahydrofurfuryl alcohol, which is frequently used as a precursor for specialty chemicals. Furfural is also used for the recovery of lubricants from cracked crude oil, pine oils, special adhesives, liquid-liquid extraction, and as a flavoring agent [18].

The largest producer of furfural is China, with a production capacity of about 220,000 tons per year. Large producers of furfural can also be found in the Dominican Republic, with 32,000 tons per year, and in South Africa, with 20,000 tons per year. These three countries account for about $90 \%$ of global furfural production capacity [18].

In 1921, Quaker Oats implemented the first commercial process for the production of furfural. In the late 1990s, SupraYield, a modification of the Quaker Oats process, was introduced. This process was commercialized in 2009 by the Proserpine Cooperative Sugar Mill in Queensland, Australia [20]. In Indonesia, a plant with the SupraYield process was planned in 2019 [21].

Table 3 shows the various furfural production processes currently under development or on an industrial scale that have been identified in this work. The first four processes are already industrially implemented manufacturing processes for furfural. All of the other listed processes are experiments or concepts by companies or scientists.

Table 3. Identified various processes for the production of furfural (derived from the literature [9]).

\begin{tabular}{|c|c|c|c|c|c|}
\hline Company/Group & Process Type & $\begin{array}{l}\text { Temperature } \\
\text { in }{ }^{\circ} \mathrm{C}\end{array}$ & Catalyst & Yield in \% & By-Products \\
\hline Quaker Oats & Batch & 153 & $\mathrm{H}_{2} \mathrm{SO}_{4}$ & $<50$ & n.s. \\
\hline Quaker Oats & Continuous & 184 & $\mathrm{H}_{2} \mathrm{SO}_{4}$ & 55 & n.s. \\
\hline Huaxia/Westpro & Continuous & $160-165$ & $\mathrm{H}_{2} \mathrm{SO}_{4}$ & $35-50$ & $\begin{array}{c}\text { Methanol, } \\
\text { acetone, } \\
\text { acetic acid, and } \\
\text { levulinic acid }\end{array}$ \\
\hline Zeitsch/SupraYield & Continuous & 240 & $\mathrm{H}_{2} \mathrm{SO}_{4}$ & $50-70$ & n.s. \\
\hline Vedernikovs & Continuous & 188 & $\mathrm{H}_{2} \mathrm{SO}_{4}$ & 75 & $\begin{array}{l}\text { Acetic acid and } \\
\text { ethanol }\end{array}$ \\
\hline Biofine & Continuous & 190-200 & $\mathrm{H}_{2} \mathrm{SO}_{4}$ & 70 & $\begin{array}{l}\text { Levulinic acid, } \\
\text { formic acid, and } \\
\text { carbon }\end{array}$ \\
\hline Abatzoglou and staff & Continuous & $190-240$ & $\mathrm{H}_{2} \mathrm{SO}_{4}$ & 65 & Hexose solution \\
\hline $\begin{array}{c}\text { De Jong and } \\
\text { Marcotullio/MTC }\end{array}$ & Continuous & 180 & $\mathrm{H}_{2} \mathrm{SO}_{4}$ & 85 & $\begin{array}{l}\text { HMF and } \\
\text { cellulosic } \\
\text { residues }\end{array}$ \\
\hline Mandalika and Runge & Batch & 170 & $\mathrm{H}_{2} \mathrm{SO}_{4}$ & 80 & $\begin{array}{l}\text { Cellulosic } \\
\text { residues }\end{array}$ \\
\hline Alonso and staff & Batch & 170 & $\mathrm{H}_{2} \mathrm{SO}_{4} /$ Mordenit & $81 / 87$ & Levulinic acid \\
\hline Mao and staff & Batch & 190 & $\begin{array}{c}\text { Acetic } \\
\text { acid/FeCl } 3\end{array}$ & 73 & $\begin{array}{l}\text { Cellulosic } \\
\text { residues and } \\
\text { lignin }\end{array}$ \\
\hline
\end{tabular}


Currently, continuous processes are used, such as the Huaxia/Westpro processes and the SupraYield process [22].

The Chinese Huaxia Furfural Technology modified by Westpro is an example of a continuous process technology that can process corncobs, rice husks, and other biogenic raw materials. As this is a proven process in current use, and information on material flows is publicly available, it has been selected for further process analysis in this paper.

The manufacturing process uses fixed-bed reactors and continuous dynamic refining, which enable a furfural yield of between $35 \%$ and $50 \%$ at low production costs [18].

\section{Results of the Analyses}

\subsection{Analysis of HMF Production after the Pilot Process of Kougioumtzis}

The technological process of HMF production after the pilot process of the authors of [15] is shown in Figure 1. The pilot plant processed $1500 \mathrm{~kg}$ biomass per hour. The biomass is first crushed to 0.3 to 1 $\mathrm{mm}$ and then mixed with diluted sulfuric acid in a ratio of 1:9.

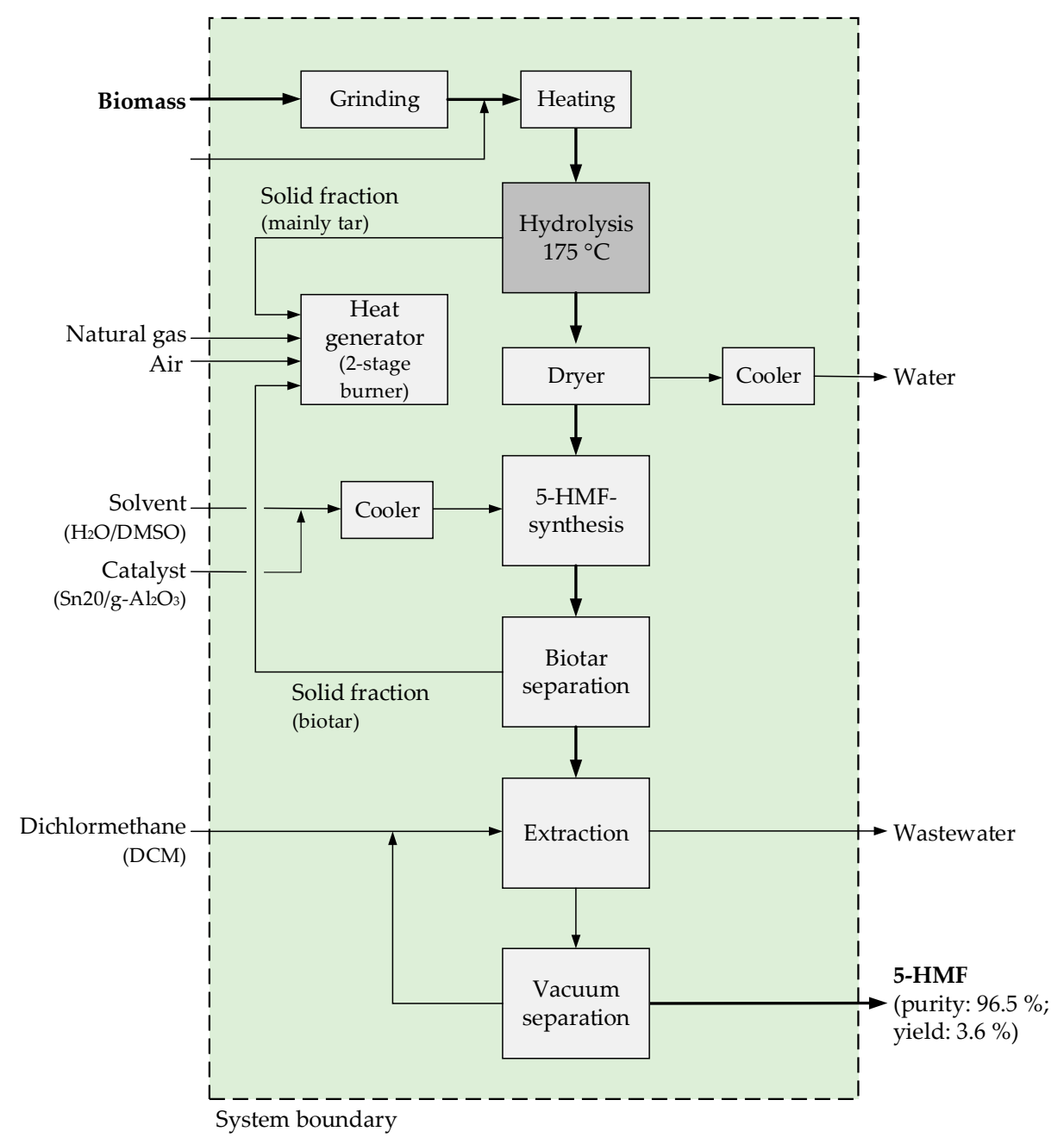

Figure 1. Production process of HMF (following the pilot process of the literature [15]).

Subsequently, hydrolysis is carried out in a reactor at a temperature of approximately $175^{\circ} \mathrm{C}$. Here, the cellulose part of the biomass is mainly converted into C6-monosaccharides (especially glucose) and other by-products. After drying, the hydrolysate stream undergoes HMF synthesis.

The glucose-rich hydrolysate stream first undergoes an evaporation step to increase the glucose concentration. Then, DMSO as a solvent and a solid catalyst $\left(\mathrm{Sn} 20 / \gamma-\mathrm{Al}_{2} \mathrm{O}_{3}\right)$ are added to allow 
for the selective synthesis of HMF. DMSO is particularly effective, because it stabilizes the furanose form of fructose and accelerates dewatering. The solvent stream contains only $20 \%$ water and $80 \%$ DMSO. During synthesis, most of the glucose is dehydrated to HMF, with the simultaneous production of by-products and biotar. After the HMF reactor, the biotar is separated and fed to the incinerator to support the heat demand of the process. The generated HMF stream is first extracted with dichloromethane (DCM) in a liquid-liquid mixture. HMF is mainly transferred into the organic circuit, while the raffinate is generated as waste water (approximately $150 \mathrm{~kg} / \mathrm{h}$ ). The charged organic solvent then flows into a three-stage separation step, in which three expansion tanks operate under vacuum conditions. This is where HMF is separated from the solvent. The latter can be recovered to $98 \%$ and is circulated. HMF is recovered as an end product with a purity of over $96.5 \%$. At a yield of approximately $54 \mathrm{~kg} / \mathrm{h}, 3.6 \%$ of the biomass starting materials are converted into HMF [15].

The process balance for the investigated HMF production is very well documented, and the mass and energy flows could be conclusively reconstructed. Figure 2 shows the input and output flows for the process described above in relation to $1 \mathrm{~kg}$ HMF. The catalysts used $\left(\mathrm{H}_{2} \mathrm{SO}_{4} / \mathrm{H}_{2} \mathrm{O}\right.$ and $\mathrm{Sn} 20 / \gamma-\mathrm{Al}_{2} \mathrm{O}_{3}$ ) are not shown in Figure 2 , as they are run in a cycle and have a long service life.

\begin{tabular}{|c|c|}
\hline \multicolumn{2}{|l|}{ Inputs (per kg HMF) } \\
\hline $\begin{array}{l}\text { Electrical energy demand } \\
\text { for components }\end{array}$ & $7.2 \mathrm{kWh}$ \\
\hline Heat energy demand & $174.3 \mathrm{kWh}$ \\
\hline Biomass & $27.78 \mathrm{~kg}$ \\
\hline Dimethlysulfoxide & $248.67 \mathrm{~kg}$ \\
\hline Dichlormethane & $61.48 \mathrm{~kg}$ \\
\hline Water & $252 \quad \mathrm{~kg}$ \\
\hline Transportation & $\begin{array}{r}\text { rail } 0.6 \mathrm{tkm} \\
\text { Truck } 0.1 \mathrm{tkm}\end{array}$ \\
\hline
\end{tabular}

\begin{tabular}{|l|r|}
\hline \multicolumn{2}{|l|}{ Outputs (per kg HMF) } \\
\hline $\mathrm{HMF}$ & $1 \quad \mathrm{~kg}$ \\
\hline Biotar & $23.33 \mathrm{~kg}$ \\
\hline Co-products & $3.61 \mathrm{~kg}$ \\
\hline Waste water & $643.33 \mathrm{~kg}$ \\
\hline Water & $197.33 \mathrm{~kg}$ \\
\hline $\mathrm{CO}_{2}$ & $342-1259 \mathrm{~kg}$ \\
\hline
\end{tabular}

Figure 2. Material and energy flows as well as $\mathrm{CO}_{2}$ emissions during $\mathrm{HMF}$ synthesis (according to the pilot process of the authors of [15]).

The range of $\mathrm{CO}_{2}$ emissions is between 326 and $1159 \mathrm{~kg}$ of $\mathrm{CO}_{2} / \mathrm{kg}$ HMF. The provision and recovery of DCM in particular has an impact here. A $98 \%$ recovery of DCM results in a specific $\mathrm{CO}_{2}$ emission of $208 \mathrm{~kg} \mathrm{CO} / \mathrm{kg} \mathrm{HMF}$, and a $90 \%$ recovery $1042 \mathrm{~kg} \mathrm{CO}_{2} / \mathrm{kg} \mathrm{HMF}$ (own calculation with values from the literature [23]). In addition, the variance of the transport distance for the truck (200 to $600 \mathrm{~km}$ ) and for the water treatment has an impact on $\mathrm{CO}_{2}$ emissions. The latter, however, are negligible with a $0.01 \%$ share of total $\mathrm{CO}_{2}$ emissions. The DMC supply dominates $\mathrm{CO}_{2}$ emissions with $64 \%$ to $90 \%$, followed by heat supply ( $7 \%$ to $26 \%$ ). The range of $\mathrm{CO}_{2}$ emissions is shown in Table 4 .

The process consumes significant amounts of $\mathrm{DCM}, \mathrm{a} \mathrm{CO}$ intensive material. Optimization work must therefore primarily focus on DCM consumption, for example, by recycling the DCM as completely as possible in the process.

If only the energy demand of the production process without upstream processes is considered (see Figure 3), it is clear that energy consumption is dominated by steam generation for preheating the hydrolysis with $62.9 \mathrm{kWh} / \mathrm{kg}$ HMF and hydrolysis with $137.9 \mathrm{kWh} / \mathrm{kg}$ HMF. The drying step prior to HMF synthesis was identified as the third largest energy consumer ( $34.8 \mathrm{kWh} / \mathrm{kg} \mathrm{HMF}$ ). 
Table 4. $\mathrm{CO}_{2}$ emissions during the production of HMF (according to the pilot process of the authors of [15]).

\begin{tabular}{cc}
\hline Process & $\begin{array}{c}\mathbf{C O}_{\mathbf{2}} \text { in } \\
\mathbf{g C O}_{2} / \mathbf{k g ~ H M F}\end{array}$ \\
\hline Dichloromethane & $208,413-1,042,065$ \\
Heat & 85,224 \\
Natural gas & 23,912 \\
DMSO & 4849 \\
Components & 3542 \\
Sulfuric acid & 44.4 \\
Transport: truck & $17.8-53.4$ \\
Transport: train & 2.4 \\
Water treatment & $1.2-6.2$ \\
Total: & $326,006-1,159,699$ \\
\hline
\end{tabular}

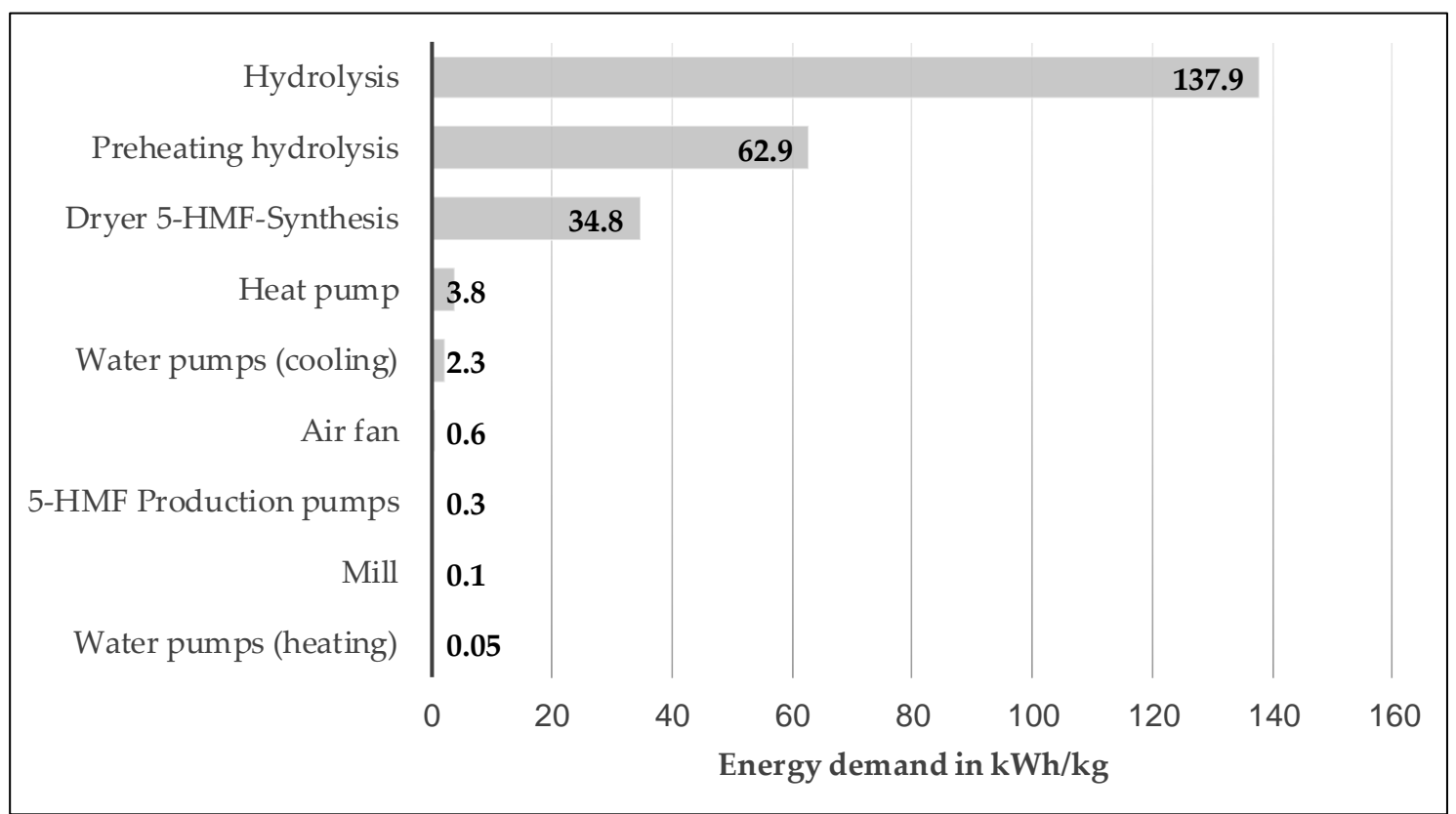

Figure 3. Energy consumption in the synthesis of HMF (according to the pilot process of the literature [15]).

The substitution of fossil energy sources during the generation of process heat has already been exhausted by returning the solid fraction to the dual fuel burner. The greatest potential for reducing the primary energy requirements and $\mathrm{CO}_{2}$ emissions lies in the use of renewable energy or biomass. See Supplementary Materials for detailed information concerning the process data.

\subsection{Analysis of Furfural Production Based on the Huaxia Technology Modified by Westpro}

The procedural steps of the Huaxia Furfural Technology modified by Westpro are shown in Figure 4. They essentially comprise the pretreatment, hydrolysis, refining, and recovery of by-products such as acetic acid and levulinic acid [18]. In this work, only the processes within the dashed system boundary that are necessary for the production of furfural were investigated. The further processing of residual and by-products, for example levulinic acid, a platform chemical used in textile printing [24], was not investigated. 


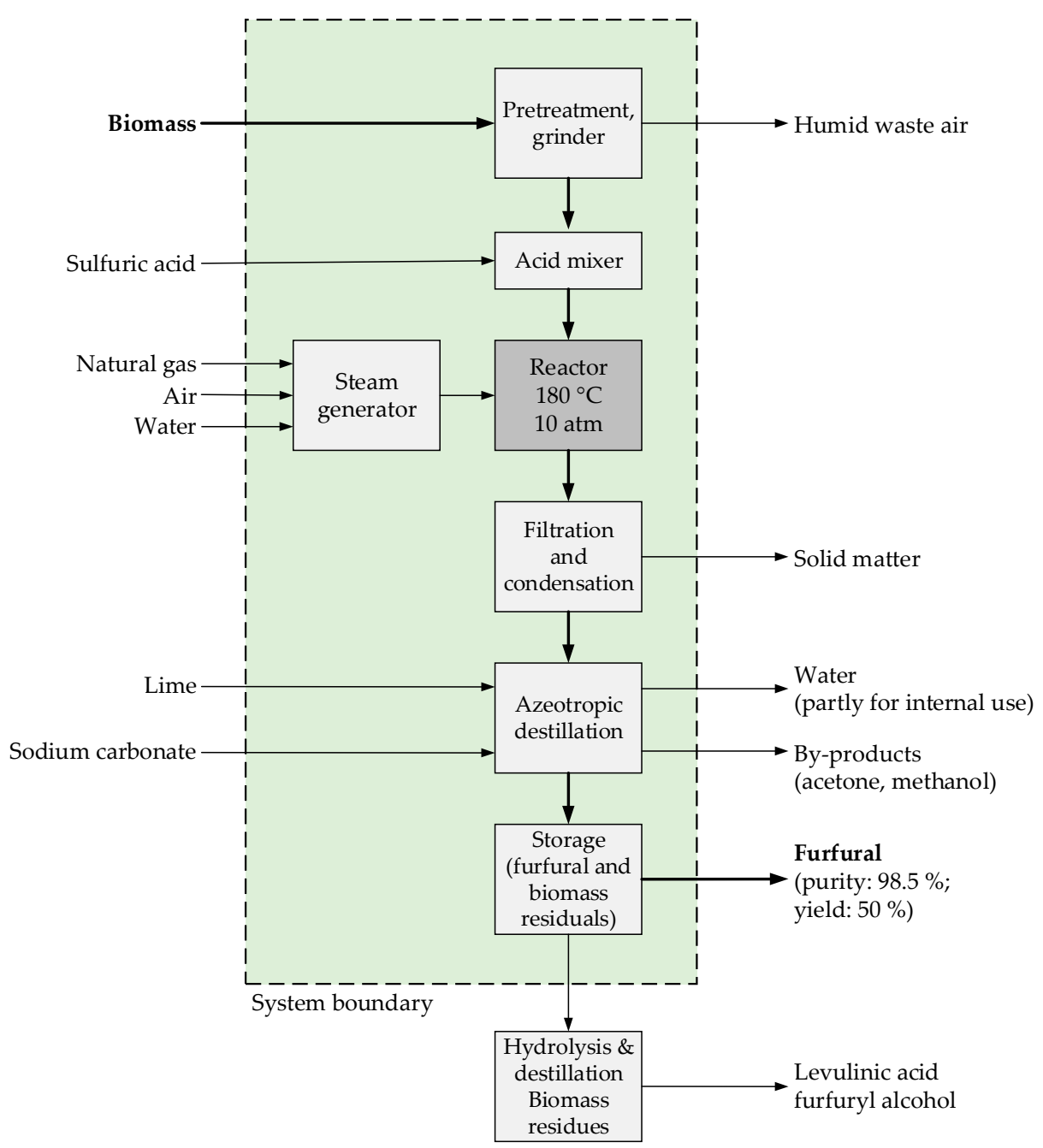

Figure 4. Production process for the continuous production of furfural using the Huaxia Furfural technology. Modified by Westpro (according to the authors of [18]).

The raw materials are pretreated, for example, by grinding corn cobs to a size of $3-10 \mathrm{~mm}$. The pre-treated materials are mixed with sulfuric acid and fed to a steel reactor or fermenter. Furfural is obtained in this reactor at a pressure of $10 \mathrm{bar}$ with hot steam at $180^{\circ} \mathrm{C}$. The furfural-saturated steam ejected from the reactor is filtered to remove solid particles, and is then condensed at $60^{\circ} \mathrm{C}$. The condensate undergoes an azeotropic distillation to achieve a higher furfural concentration. Lime $(\mathrm{CaO})$ is used to remove water. The azeotropic distillation is carried out continuously. The resulting water $\left(\mathrm{H}_{2} \mathrm{O}\right)$ is used internally, as far as possible. The resulting acid is neutralized with sodium carbonate. By-products from distillation, such as acetone and methanol, are removed. The distillates are collected in storage tanks under a vacuum at different reflux conditions. Furfural has a purity of over $98.5 \%$ with a yield of $45 \%-50 \%$ being theoretically possible [18].

The described production plant produces 1500 tons of furfural per year ( $\mathrm{t} / \mathrm{a})$ [18]. This corresponds to about 171 kilograms per hour $(\mathrm{kg} / \mathrm{h})$. It was assumed, in the context of the analysis, that the plant is not used at $100 \%$ capacity, and is operated at approximately $6500 \mathrm{~h}$ per year (i.e., approximately a $74 \%$ capacity). With these assumptions, a furfural output of approximately $231 \mathrm{~kg} / \mathrm{h}$ or $0.06 \mathrm{~kg} / \mathrm{s}$ will occur.

The furfural production process under investigation was very well documented in the process balance, and could thus be coherently verified. Figure 5 shows the input and output flows for the process described above in relation to $1 \mathrm{~kg}$ of furfural. 


\begin{tabular}{|l|c|}
\hline \multicolumn{2}{|l|}{ Inputs (per kg Furfural) } \\
\hline $\begin{array}{l}\text { Electrical energy demand } \\
\text { for components }\end{array}$ & $0.1 \mathrm{kWh}$ \\
\hline Heat energy demand & $26.4 \mathrm{kWh}$ \\
\hline Biomass & $6.6 \mathrm{~kg}$ \\
\hline Lime & $0.5 \mathrm{~kg}$ \\
\hline Sodium carbonate & $0.01 \mathrm{~kg}$ \\
\hline Water & $30 \quad \mathrm{~kg}$ \\
\hline
\end{tabular}

\begin{tabular}{|l|r|}
\hline Transportation & $\begin{array}{r}\text { rail } 0.6 \mathrm{tkm} \\
\text { Truck } 0.2 \mathrm{tkm}\end{array}$ \\
\hline
\end{tabular}

\begin{tabular}{|l|c|}
\hline \multicolumn{2}{|l|}{ Outputs (per kg Furfural) } \\
\hline Furfural & $1 \mathrm{~kg}$ \\
\hline Levulinic acid & $1.33 \mathrm{~kg}$ \\
\hline Furfuryl alcohol & $1 \mathrm{~kg}$ \\
\hline Methanol & $0.17 \mathrm{~kg}$ \\
\hline Acetone & $0.17 \mathrm{~kg}$ \\
\hline Acetic acid & $0.53 \mathrm{~kg}$ \\
\hline Waste water & $6.6 \mathrm{~kg}$ \\
\hline $\mathrm{CO}_{2}$ & $13-14.33 \mathrm{~kg}$ \\
\hline
\end{tabular}

Figure 5. Material and energy flows, as well as $\mathrm{CO}_{2}$ emissions from the synthesis of furfural (using the Huaxia Furfural technology, modified by Westpro).

The range of $\mathrm{CO}_{2}$ emissions lies between 13.45 and $14.33 \mathrm{~kg} \mathrm{CO}_{2} / \mathrm{kg}$ furfural, and results from the various fossil fuels used (gas, oil, and coal) for the calcination of limestone. If the truck transport distances are also varied between 200 and $600 \mathrm{~km}$, the distribution of $\mathrm{CO}_{2}$ emissions shown in Table 5 occurs. Heat supply dominates the energy demand and thus also $\mathrm{CO}_{2}$ emissions, followed by the lime production.

Table 5. $\mathrm{CO}_{2}$ emissions in the production of furfural (using the Huaxia Furfural technology modified by Westpro).

\begin{tabular}{cc}
\hline Process & $\begin{array}{c}\mathbf{C O}_{2} \text { in } \\
\mathbf{g C O}_{2} / \mathbf{k g ~ F u r f u r a l}\end{array}$ \\
\hline Heat & 12,933 \\
Lime & $370-1215$ \\
Components & 62 \\
Sulfuric acid & 60 \\
Transport: truck & $17.8-53.4$ \\
Sodium carbonate & 4.4 \\
Transport: train & 2.4 \\
Total: & $13,450-14,330$ \\
\hline
\end{tabular}

If we look exclusively at the energy requirements of the production process, without upstream processes such as lime production (see Figure 6), it is apparent that both steam generation with $23.2 \mathrm{kWh} / \mathrm{kg}$ furfural as well as the operation of the azeotropic distillation plant with $3.3 \mathrm{kWh} / \mathrm{kg}$ furfural dominate.

This means that the greatest potential for reducing the primary energy demand and $\mathrm{CO}_{2}$ emissions lies in the substitution of fossil energy sources, especially in the production of process heat by renewable energy or biomass. To this end, it would make sense to use the solid discharged with the filtering process as an energy source for steam generation, and thus reduce natural gas consumption. This would be possible with the aid of a dual fuel burner, if the calorific value of the solid was sufficient. See Supplementary Materials for detailed information concerning the process data. 


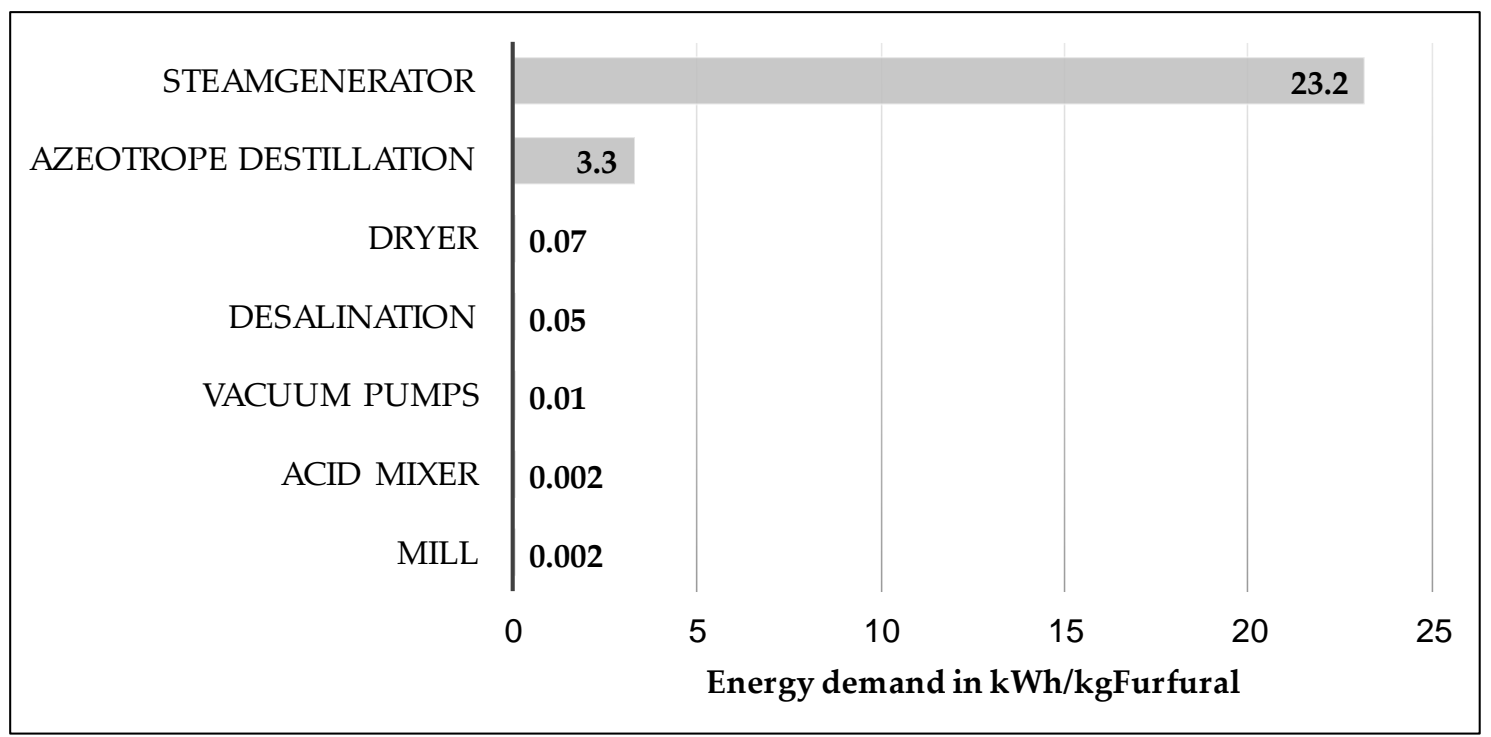

Figure 6. Energy intensity in the synthesis of furfural (when using the Huaxia Furfural technology modified by Westpro).

\section{Discussion}

The process routes for the production of HMF are well known, but there is no established large-scale production process yet. The pilot process of the authors of [15] for the production of HMF was investigated and verified. The total energy requirement is $181.5 \mathrm{kWh} / \mathrm{kg} \mathrm{HMF}$, and between 326 and $1159 \mathrm{~kg} \mathrm{CO}_{2} / \mathrm{kg} \mathrm{HMF}$ is emitted.

Because of the very low yield compared with furfural, the production of HMF is associated with a significantly higher specific energy requirement, and thus also much higher $\mathrm{CO}_{2}$ emissions. In both processes, the heat supply causes the highest energy consumption, and thus the highest $\mathrm{CO}_{2}$ emissions. By recycling the biomass, a considerable part of the energy demand can be covered. Further savings are possible by increasing the efficiency of the aggregates. The general objective should be to develop low-energy processes with higher yields.

In the production of HMF, the consumption of DCM should be minimized in further research work, for example, through improved circulation. The production of $\mathrm{DCM}$ is a major $\mathrm{CO}_{2}$ driver in this process. The large-scale and economical production of HMF with a high yield still has to be developed.

For the synthesis of furfural, the Huaxia Furfural Technology modified by Westpro was identified as a large-scale production process route. In addition to the SupraYield process, it is an established process for the production of furfural. The total energy requirement is $26.5 \mathrm{kWh} / \mathrm{kg}$ furfural, and between 13.45 and $14.33 \mathrm{~kg} \mathrm{CO}_{2} / \mathrm{kg}$ furfural is emitted.

For the production of furfural, the use of two-phase systems has shown promising results in terms of yields and selectivity. As the recovery of solvents is problematic, the market maturity of these systems is not yet foreseeable [20]. Current efforts focus on the development of new production technologies to obtain furfural in a cost-effective and environmentally friendly way [17].

In addition to $\mathrm{CO}_{2}$, other environmental impacts are to be identified through life cycle assessments, for example, caused by biomass provision or by the auxiliary materials used.

\section{Conclusions and Outlook}

Within the scope of the present study, for two selected processes for the production of HMF and furfural from cellulosic biomass, the main energy consumers and the main sources of $\mathrm{CO}_{2}$ emissions could be clearly identified, despite the limited information available. A robust basis for further investigations, such as the preparation of life cycle assessments and economic considerations, was created. Within the framework of life cycle assessments, further critical environmental burdens and 
levers for their elimination are to be identified. The operating costs of the investigated processes can be derived directly from the results of the investigations. For the determination of the investment costs, further investigations are planned for the design and dimensioning of the apparatus for both examined processes. The present work and further research should support the development of a novel biorefinery for the production of several platform chemicals in one process. This biorefinery must have both economic and ecological advantages over the competing processes.

Supplementary Materials: The following are available online at http://www.mdpi.com/2227-9717/8/1/119/s1: Process verification data: Schoeppe-etal-Biorefinery-Energy-Material-CO2-HMF-Furfural-Processdata-EN-202001-10.xlsx.

Author Contributions: Conceptualization, H.S. and P.K.-M.; methodology, H.S.; validation, H.S., P.K.-M., and R.E.; formal analysis, H.S.; investigation, H.S.; data curation, H.S., P.K.-M., and R.E.; writing (original draft preparation), P.K.-M. and R.E.; writing (review and editing), P.K.-M. and R.E.; visualization, P.K.-M. and R.E.; supervision, P.K.-M.; project administration, P.K.-M.; funding acquisition, P.K.-M. All authors have read and agreed to the published version of the manuscript.

Funding: This research was funded by Bundesministerium für Bildung und Forschung, grant number 031B0664C. The office consortium of the State of Baden-Württemberg in Germany funded $50 \%$ of the publication costs in open access. The remaining balance was funded by the research grants of the corresponding author from Reutlingen University.

Acknowledgments: This paper is a result of research work at Reutlingen University.

Conflicts of Interest: The authors declare no conflict of interest.

\section{References}

1. VCI. VCI-Factbook 05. Die Formel Ressourceneffizienz. 2012. Available online: https://www.vci.de/presse/ factbooks/2012-07-25-vci-factbook-05-die-formel-ressourceneffizienz-vci.jsp (accessed on 3 December 2019).

2. IEA International Energy Agency. Oil 2018. Analysis and Forecasts to 2023. 2018. Available online: https://www.iea.org/reports/oil-2018 (accessed on 10 January 2020).

3. VCI. Einsatz Nachwachsender Rohstoffe in der Chemischen Industrie unter der Anwendung von Massenbilanzansätzen. 2017. Available online: https:/www.vci.de/themen/energie-klima-rohstoffe/ rohstoffe/einsatz-nachwachsender-rohstoffe-in-der-chemischen-industrie-anwendung-von-massenbilanzansaetzen-integration-in-bestehende-produktions-und-lieferketten.jsp (accessed on 3 December 2019).

4. Jong, E.D.; Langeveld, H.; van Ree, R. IEA Bioenergy Task 42 Biorefinery. 2009. Available online: https://www. iea-bioenergy.task42-biorefineries.com/en/ieabiorefinery/Publications.htm (accessed on 10 January 2020).

5. Kohli, K.; Prajapati, R.; Sharma, B. Bio-Based Chemicals from Renewable Biomass for Integrated Biorefineries. Energies 2019, 12, 233. [CrossRef]

6. Bozell, J.J.; Petersen, G.R. Technology development for the production of biobased products from biorefinery carbohydrates-The US Department of Energy's “Top 10" revisited. Green Chem. 2010, 12, 539. [CrossRef]

7. Werpy, T.; Petersen, G. Top Value Added Chemicals From Biomass. Volume I: Results of Screening for Potential Candidates from Sugars and Synthesis Gas; U.S. Department of Energy: Oak Ridge, TN, USA, 2004.

8. Van Putten, R.-J.; van der Waal, J.C.; de Jong, E.; Rasrendra, C.B.; Heeres, H.J.; de Vries, J.G. Hydroxymethylfurfural, a versatile platform chemical made from renewable resources. Chem. Rev. 2013, 113, 1499-1597. [CrossRef] [PubMed]

9. Cai, C.M.; Zhang, T.; Kumar, R.; Wyman, C.E. Integrated furfural production as a renewable fuel and chemical platform from lignocellulosic biomass. J. Chem. Technol. Biotechnol. 2014, 89, 2-10. [CrossRef]

10. KIT. Chemische Produkte auf Erneuerbarer Grundlage; KIT Entwickelt Neues Verfahren zur Industriellen Herstellung der Plattformchemikalie 5-HMF-Anlage der AVA Biochem Nimmt Produktion auf; Karlsruher Institut für Technologie: Karlsruhe, Germany, 2014.

11. Salak Asghari, F.; Yoshida, H. Acid-Catalyzed Production of 5-Hydroxymethyl Furfural from d -Fructose in Subcritical Water. Ind. Eng. Chem. Res. 2006, 45, 2163-2173. [CrossRef]

12. Rapp, K.M.; Daub, J. Herstellung und Derivatisierung von 5-Hydroymethylfurfural. In Nachwachsende Rohstoffe: Perspektiven für die Chemie; Eggersdorfer, M., Warwel, S., Wulff, G., Eds.; VCH: Weinheim, Germany, 1993; pp. 183-196. ISBN 3527290192. 
13. Rosatella, A.A.; Simeonov, S.P.; Frade, R.F.M.; Afonso, C.A.M. 5-Hydroxymethylfurfural (HMF) as a building block platform: Biological properties, synthesis and synthetic applications. Green Chem. 2011, 13, 754. [CrossRef]

14. Dibenedetto, A.; Aresta, M.; Di Bitonto, L.; Pastore, C. Organic Carbonates: Efficient Extraction Solvents for the Synthesis of HMF in Aqueous Media with Cerium Phosphates as Catalysts. CHEMSUSCHEM 2016, 9 , 118-125. [CrossRef] [PubMed]

15. Kougioumtzis, M.A.; Marianou, A.; Atsonios, K.; Michailof, C.; Nikolopoulos, N.; Koukouzas, N.; Triantafyllidis, K.; Lappas, A.; Kakaras, E. Production of 5-HMF from Cellulosic Biomass: Experimental Results and Integrated Process Simulation. Waste Biomass Valoriz. 2018, 9, 2433-2445. [CrossRef]

16. Montané, D.; Salvadó, J.; Torras, C.; Farriol, X. High-temperature dilute-acid hydrolysis of olive stones for furfural production. Biomass Bioenerg. 2002, 22, 295-304. [CrossRef]

17. Mariscal, R.; Maireles-Torres, P.; Ojeda, M.; Sádaba, I.; López Granados, M. Furfural: A renewable and versatile platform molecule for the synthesis of chemicals and fuels. Energy Environ. Sci. 2016, 9, 1144-1189. [CrossRef]

18. Win, D.T. Furfural-Gold from Garbage. Assumpt. Univ. J. Technol. 2005, 8, 185-190.

19. Hayes, D.J.; Fitzpatrick, S.; Hayes, M.H.B.; Ross, J.R.H. The Biofine Process-Production of Levulinic Acid, Furfural, and Formic Acid from Lignocellulosic Feedstocks. In Biorefineries-Industrial Processes and Products; Kamm, B., Gruber, P.R., Kamm, M., Eds.; Wiley-VCH Verlag GmbH: Weinheim, Germany, 2005; pp. 139-164. ISBN 9783527619849.

20. Dashtban, M.; Gilbert, A.; Fatehi, P. Production of Furfural: Overview and Challenges. J. Sci. Technol. For. Prod. Process. 2012, 2, 44-53.

21. Hidayat, N.; Hidayat, A.N.; Gozan, M. Preliminary design of corncob based furfural plant. In AIP Conference Proceedings 2062, Proceedings of the 10th International Meeting of Advances in Thermofluids (IMAT 2018): Smart City: Advances in Thermofluid Technology in Tropical Urban Development, Bali, Indonesia, 16-17 November 2018; AIP Publishing, Ed.; AIP Publishing: Melville, NY, USA, 2019; pp. 020048-1-020048-9.

22. Karinen, R.; Vilonen, K.; Niemelä, M. Biorefining: Heterogeneously catalyzed reactions of carbohydrates for the production of furfural and hydroxymethylfurfural. CHEMSUSCHEM 2011, 4, 1002-1016. [CrossRef]

23. Boustead, I. Ecoprofile of Chloromethanes. 1997. Available online: https://scholar.google.com/scholar?hl= de\&as_sdt=0\%2C5\&q=Ecoprofile+of + Chloromethanes\&btnG $=($ accessed on 3 December 2019).

24. Eseyin, A.E.; Steele, P.H. An overview of the applications of furfural and its derivatives. Int. J. Algebra Comput. 2015, 3, 42. [CrossRef] 